\title{
LIMITED PROTEOLYSIS IN THE CARBOXY-TERMINAL REGION OF BARLEY $\beta$-AMYLASE
}

by

\author{
ROBERT LUNDGARD and BIRTE SVENSSON
}

Department of Chemistry, Carlsberg Laboratory

Gamle Carlsberg Vej 10, DK-2500 Copenhagen Valby

Keywords: Trypsin, isoelectric focusing, RP-HPLC, gas-phase sequencing

\begin{abstract}
Trypsin converts a purified $\beta$-amylase component from barley, $\beta$-amylase 1 , to another catalytically active form of the enzyme characterized by a higher isoelectric point. The two main peptide fragments released during this limited proteolysis were purified by reverse-phase HPLC. Their complete sequences were determined to comprise 22 and 23 amino acid residues starting at the same $\mathrm{NH}_{2}$-terminal residue. Barley $\beta$-amylases are $\mathrm{NH}_{2}$-terminally blocked and the released peptides were confirmed to stem from the COOH-terminal end of the protein by comparison with the sequence deduced from a cDNA clone of barley $\beta$-amylase (KREIS, WILLIAMSON, BUXTON, PYWell. HeJgaARD and SVEndSEN, in preparation).
\end{abstract}

\section{INTRODUCTION}

$\beta$-Amylase, 1,4- $\alpha$-D-glucan maltohydrolase (EC 3.2.1.2), is an exoglucanase that catalyses the release of $\beta$-maltose from the non-reducing ends of starch and related compounds. The enzyme is a major protein in the starchy endosperm of ungerminated barley seeds (2). Previous investigations agree on the fact that this enzyme shows polymorphism with respect to both size and charge $(6,8,12)$. For barley and wheat $\beta$-amylase, various explanations are suggested for the occurrence of multiple forms such as formation of intermolecular disulfide bonds $(8,12)$, thiol/disulfide interchange (6), association with other barley proteins (3), proteolysis $(2,5,7)$, deamidation (3), and expression of different genes (1). No investigations into the relationship between primary structures of the different forms of cereal $\beta$-amylases have been reported. In the present study it is shown that trypsin treatment of a homogeneous form of barley $\beta$-amylase leads to another form of the enzyme by release of peptides from the $\mathrm{COOH}$ terminal region.

\section{MATERIALS AND METHODS}

\subsection{Materials}

Barley seeds (Hordeum vulgare L., cv. Gula) were from the 1985 crop grown at the Carlsberg Research Farm.

DPCC treated trypsin (Type XI) and monothioglycerol, were from Sigma, St. Louis, MO. Dithiothreitol was from Aldrich Chemie, Steinheim, F.R.G. DEAE-cellulose, DE-52, was from Whatman, Maidstone, U.K.; Merck, Darm-

Abbreviations: DPCC = diphenylcarbamyl chloride; EDTA = ethylenediaminetetraacetic acid; RP-HPLC = reverse-phase high performance liquid chromatography; TFA = trifluoroacetic acid; Tris $=2$-amino2(hydroxymethyl)-1,3-propandiol. 
stadt, F.R.G. supplied soluble starch and DEAE-Fractogel 650s. Ampholine PAGplates, pH 4.0-6.5, were from L.K.B., Bromma, Sweden. Trifluoroacetic acid and 1-propanol were from Rathburn, Walkerburn, Scotland. All other chemicals used were of analytical purity or sequanal grade.

\subsection{Methods}

\subsubsection{Purification of $\beta$-amylase 1}

A $30 \mathrm{l}$ aqueous extract of barley flour $(10 \mathrm{~kg})$ containing $0.1 \mathrm{M}$-monothioglycerol and $10 \mathrm{~mm}$ EDTA (pH 5.0) was stirred slowly for $2 \mathrm{~h}$ and allowed to settle overnight in the cold. The supernatant was removed and the flour was reextracted with 201 by the above procedure. The combined extracts were concentrated to 12 1 with a DDS 600 ultrafilter (Danish Sugar Refineries, Nakskov, Denmark) and fractionated at 20 to $60 \%$ saturation of $\left(\mathrm{NH}_{4}\right)_{2} \mathrm{SO}_{4}$. The precipitate was redissolved in water, dialyzed against $15 \mathrm{~mm}$-Tris $\mathrm{pH} 8.0$, containing 0.1 M-monothioglycerol, and applied to a DEAEcellulose column $(10 \times 23 \mathrm{~cm})$. After washing, the protein was eluted with a linear gradient from zero to $0.15 \mathrm{M}-\mathrm{NaCl}$ in the same buffer. $\beta$-Amylase eluting between 0.04 and $0.06 \mathrm{M}$ of $\mathrm{NaCl}$ was rechromatographed on DEAE-Fractogel TSK$650 \mathrm{~s}(2.5 \times 50 \mathrm{~cm})$ employing the above buffer and a gradient from zero to $0.075 \mathrm{M}-\mathrm{NaCl}$. From this chromatography the $\beta$-amylase eluting between 0.05 and $0.06 \mathrm{M}-\mathrm{NaCl}$ was rechromatographed to give homogeneous $\beta$-amylase 1 . Further details on the purification and characterization of the four main components of barley $\beta$-amylase will be published elsewhere (LUNDGARD and SVENSSON, in preparation).

\subsubsection{Limited proteolysis}

$\beta$-Amylase $1(3.6 \mathrm{mg})$, purified as described (section 2.2.1), was incubated with trypsin (10 $\mu \mathrm{g})$ for $4 \mathrm{~h}$ at $30^{\circ} \mathrm{C}$ in $20 \mathrm{~mm}$-ammonium bicarbonate $\mathrm{pH} 8.0$ containing $1 \mathrm{~mm}$-dithiothreitol ( $2 \mathrm{ml})$. Prior to analytical isoelectric focusing the protease activity was inhibited by lowering the $\mathrm{pH}$ with the addition of $10 \mu \mathrm{l} 0.1 \mathrm{M}$-citrate buffer pH 3.2 to $15 \mu$ l of the incubation mixture. Estimation of $\mathrm{pI}$ by isoelectric focusing $(\mathrm{pH}$
4.0-6.5) was performed according to the manufacturers' instruction (13). Protein was stained with Coomassie brilliant blue. $\beta$-Amylase activity was visualized in isoelectric focusing gels by immersion into a $2 \%$ starch solution in 50 mM-sodium acetate, $\mathrm{pH} 5.0$ and developing with $\mathrm{I}_{2} / \mathrm{KI}(10)$. For HPLC analysis the limited proteolysis incubation mixture was acidified with $1 / 10$ th the volume of $1 \mathrm{~N}-\mathrm{HCl}$ and lyophilized. The peptides were extracted from the dried protein pellet and subjected to HPLC.

\subsubsection{Purification and identification of peptides}

Reverse-phase HPLC chromatography was performed on a Waters liquid chromatography system and a J.T. Baker Wide-Pore $\mathrm{C}_{18}$ (RP $7104)$ column $(4.6 \times 250 \mathrm{~mm})$ with elution by a gradient of 2-40\% 1-propanol in $0.1 \%$ TFA over $80 \mathrm{~min}$. The flow rate was $0.5 \mathrm{ml} \cdot \mathrm{min}^{-1}$. Rechromatography was performed on a Vydac C-18 $(218 \mathrm{TPb})$ column $(5 \times 250 \mathrm{~mm})$ with elution over 60 min with 1-propanol gradients in $0.1 \%$ TFA covering an organic solvent concentration range of 7 to $13 \%$.

Amino acid analysis of peptides after acid hydrolysis $\left(6 \mathrm{~N}-\mathrm{HCl}, 24 \mathrm{~h}\right.$ at $\left.110{ }^{\circ} \mathrm{C}\right)$ was performed on a Durrum D-500 amino acid analyzer. Amino acid sequencing of peptides and proteins was done on an Applied Biosystems model $470 \mathrm{~A}$ gas-phase sequencer according to the manufacturers' instructions and with a Beckman Sequencer 890C (11), respectively. PTH-amino acids were identified by HPLC, either by the Applied Biosystems model 120A PTH analyzer or as reported (11).

\subsubsection{Assay of $\beta$-amylase}

The activity of $\beta$-amylase on soluble starch was determined by measuring the release of reducing sugar with the Nelson reagent essentially as previously described (9).

\section{RESULTS}

\subsection{Limited proteolysis}

The tryptic conversion of purified $\beta$-amylase 1 to another form of $\beta$-amylase ( $\beta$-amylase 4 ') is 


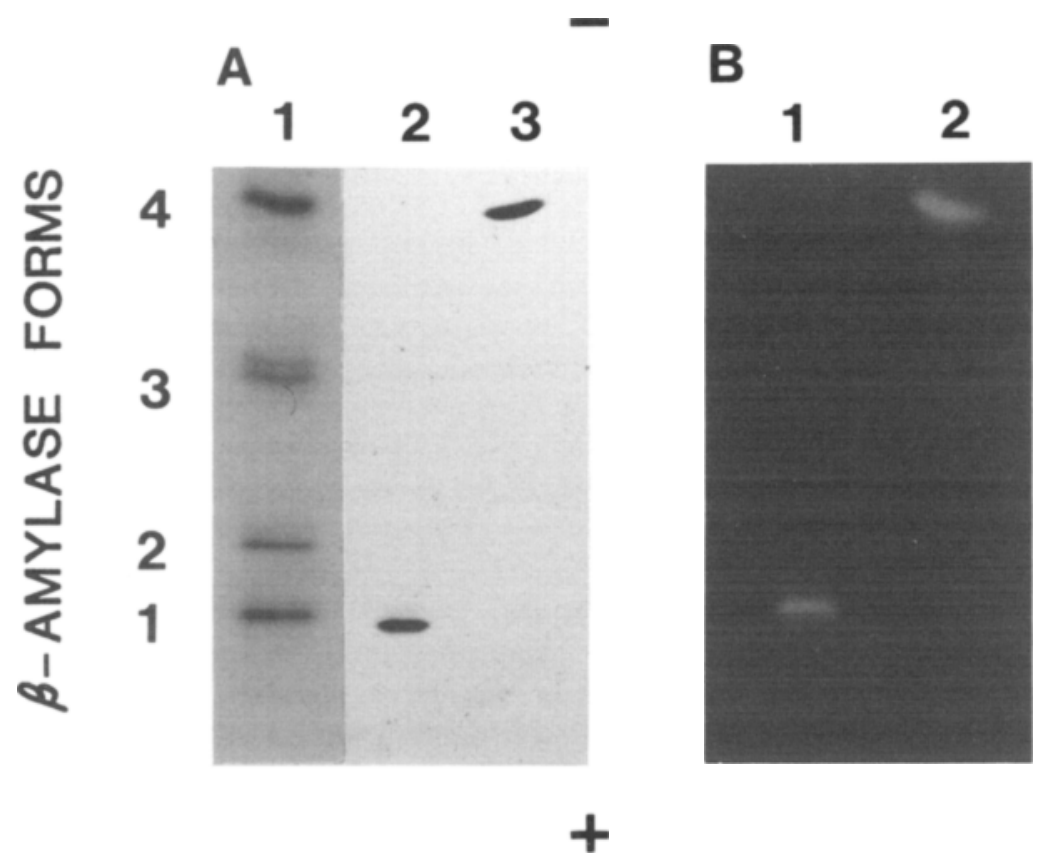

Figure 1. Isoelectric focusing (pH 4-6.5) of $\beta$-amylase 4' generated from purified $\beta$-amylase 1 by limited proteolysis with trypsin (see section 2.2.2).

A. Protein stained gel of a mixture of purified barley $\beta$-amylases I (pI 5.2), 2 (pI 5.3), 3(pI 5.5), 4 (pI 5.7) as standards (lane 1); the initial $\beta$-amylase $1(4 \mu \mathrm{g})$ at zero time of incubation with trypsin (lane 2$)$, and the resulting $\beta$-amylase 4 ' after $4 \mathrm{~h}$ incubation (lane 3 ).

B. Starch hydrolysing activity of $0.4 \mu \mathrm{g}$ of $\beta$-amylase 1 (lane 1 ) and $\beta$-amylase 4 ' (lane 2 ) at the 0 and $4 \mathrm{~h}$ incubation times, respectively.

demonstrated by analytical isoelectric focusing (Figure 1). After $4 \mathrm{~h}$ of incubation $\left(30^{\circ} \mathrm{C}\right)$ with trypsin the $\beta$-amylase 1 was completely transformed to a species migrating in isoelectric focusing gels to the same $\mathbf{p I}$ as $\beta$-amylase 4 (Figure 1A, lanes 2 and 3), one of the four main $\beta$-amylase components isolated from barley (LUNDGARD and SVENSSON, in preparation). Both $\beta$-amylase 1 and $\beta$-amylase 4 are $\mathrm{NH}_{2}$-terminally blocked. The $\beta$-amylase 4' generated by trypsin maintained amylolytic activity as shown by the starch- $\mathrm{I}_{2} / \mathrm{KI}$ activity stain (Figure $\mathrm{l}$ B, lane 2 ). During longer incubation times $(6 \mathrm{~h})$ with trypsin the $\mathrm{pI}$ of the protein remained unchanged suggesting that a stable species had formed. The intermediate forms, $\beta$-amylase 2 and 3 (see Figure 1A, lane 1), were detectable in trace amounts on activity stained gels upon prolonged incubation in starch (data not shown).
In order to determine the nature of the peptide products formed by limited proteolysis the sample was dried by lyophilization and then subjected to HPLC.

\subsection{Isolation of peptides}

Peptides from the lyophilized mixtures from tryptic treatment of $\beta$-amylase 1 were redissolved in $0.1 \%$ TFA, $20 \%$ acetic acid, or 4.5 $\mathrm{M}$-guanidine hydrochloride in $0.1 \%$ TFA and the insoluble material was removed by centrifugation. Reverse-phase HPLC of a fraction of each of the three different supernatants yielded essentially identical chromatograms and revealed only two major peptide peaks, A and B, eluting with about 40 min retention time (Figure 2 ). The peptides eluting in A and B were finally purified by rechromatography (see section 2.2.3) and 


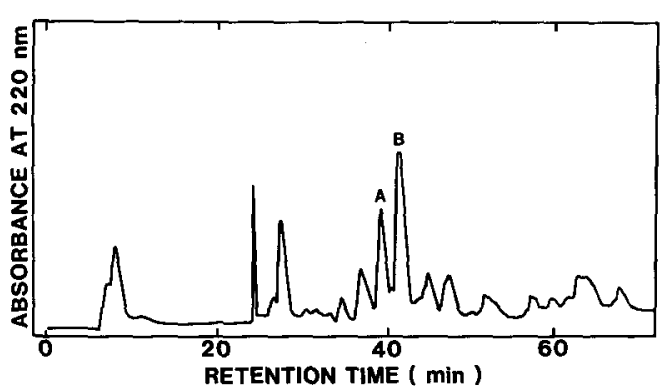

Figure 2. Reverse-phase HPLC profile of tryptic peptides released by limited proteolysis of 35 nmoles of $\beta$-amylase 1 (see section 2.2.3). The three major peaks eluting between 5 and $30 \mathrm{~min}$ were present in a zero time incubation control run and do not contain peptides.

isolated in a total yield of about $40 \%$ in relation to the amount of treated $\beta$-amylase 1 .

\subsection{Characterization of peptides}

Amino acid analyses of two peptides were very similar (Table I). Gas-phase sequencing identified 23 and 22 residues (Figure 3) in peptides A and B, respectively, which is in good agreement with the amino acid composition and indicates that the entire fragment was sequenced in both cases.

\section{DISCUSSION}

The $\mathrm{NH}_{2}$-terminal blocking of barley $\beta$-amylases 1 and 4 shows that limited proteolysis occurs at the $\mathrm{COOH}$-terminal end of the barley $\beta$-amylase 1 resulting in the formation of $\beta$-amylase 4' identified by its pl. The loss of three negative charges (two glutamic acid residues and
Table I. Amino acid composition of peptides $A$ and $B$ generated from $\beta$-amylase 1 by trypsin.

\begin{tabular}{llc}
\hline & \multicolumn{2}{c}{ Residues per peptide } \\
\cline { 2 - 3 } & $\mathrm{A}$ & $\mathrm{B}$ \\
\hline Aspartic acid & $1.1(1)$ & $0.9(1)$ \\
Threonine & $1.9(2)$ & $1.8(2)$ \\
Serine & $1.1(1)$ & $0.9(1)$ \\
Glutamic acid & $2.8(3)$ & $2.7(3)$ \\
Proline & $2.5(3)$ & $2.8(3)$ \\
Glycine & $8.0(8)$ & $8.1(8)$ \\
Alanine & $1.8(2)$ & $1.0(1)$ \\
Methionine & $1.5(2)$ & $1.5(2)$ \\
Leucine $^{\text {a }}$ & $0.9(1)$ & $1.0(1)$ \\
\hline
\end{tabular}

a) as the sum of methionine sulphoxide and methionine.

The values in parenthesis are obtained from the sequence determination.

one aspartic acid residue) by removal of peptide A from $\beta$-amylase 1 is consistent with the shift to higher isoelectric point accompanying the proteolytic conversion. Recently, the complete amino acid sequence of barley $\beta$-amylase was deduced from the nucleotide sequence of a cDNA clone (Kreis, Williamson, Buxton, Pywell, HejgaArd and Svendsen, in preparation). The sequence of the peptides isolated in the present work, with the exception of a single position (Met(17) compared to Ile, see Figure 3), are in agreement with the nucleotide sequence data, when the longer of the peptide fragments is placed with its $\mathrm{COOH}$-terminal residue at the third position from the $\mathrm{COOH}$-terminus of the protein encoded by the cDNA (Figure 3 ). Furthermore, the nucleotide sequence data verified

\section{Peptide $B(A)$}
Gly-Pro-Thr-Gly-Gly-Met-Giy-Gly-Gln-Ala
10
20
y-Glu-Leu-Pro- (Al a) - $\mathrm{COOH}$

Sequence derived from CDNA

Lys-Gly-Pro-Thr-Gly-Gly-Met-Gly-Gly-Gln-Ala-Glu-Asp-Pro-Thr-Ser-Gly-Ile-Gly-Gly-Glu-Leu-Pro-Ala-Thr-Met-Stop

Figure 3. Alignment of the amino acid sequence of peptides A, Gly(1)-Ala(23), and B, Gly(1)-Pro(22), determined by gas-phase sequencing with a sequence derived from the end of the coding region of a cDNA clone corresponding to barley $\beta$-amylase. In the nucleotide sequence the ATG codon coding for methionine is followed by the termination codon TAA.

a. Kreis. Williamson, Buxton, Pywell, Hejgatrd and Svendsen, in preparation. 
that these peptides were true tryptic fragments since they arose by cleavage of a Lys-Gly bond (Figure 3). The peptide fragments characterized, however, cover a stretch of only 23 amino acid residues and do not account for more than approximately one third of the apparent molecular weight difference between $\beta$-amylase 1 and 4 (LundGaRD and SVENSSON, in preparation). Although significant amounts of the intermediate forms, $\beta$-amylases 2 and 3 , were not observed in the present study, the actual peptides $A$ and $B$ could have been generated by conversion of $\beta$-amylase 1 to 2 on a pathway of steps leading to $\beta$-amylase 4 . The absence in the peptides $A$ and $B$ of Thr-Met and Ala-Thr-Met, respectively, which are found at the $\mathrm{COOH}$-terminus corresponding to the encoded protein (KREIS, Williamson, Buxton, Pywell, Hejgaard and SVENDSEN, in preparation), might be explained by action of carboxypeptidase(s) or other protease(s) during development of the grain and/or during extraction of the flour and subsequent protein purification. Alternatively, the Gula barley variety may have a slightly different position for the stop codon for $\beta$-amylase.

Changes in the heterogeneity of barley $(2,7)$ and wheat (5) $\beta$-amylase induced by proteolysis have been suggested previously, although structural details of the conversion were not elucidated. From the present results it seems likely that limited proteolysis of barley $\beta$-amylase at the $\mathrm{COOH}$-terminus, catalyzed by endogenous barley protease(s), contributes to the polymorphism observed for this enzyme.

\section{ACKNOWLEDGEMENTS}

Professor MARTin OtTeSEN is thanked for encouraging discussions and revision of the manuscript. We are grateful to Dr. MARTIN KREIS (Rothamsted Experimental Station, Harpenden, U.K.) for information on the nucleotide sequence of CDNA corresponding to barley $\boldsymbol{\beta}$-amylase and for permission to show a short region of the encoded protein sequence prior to publication. Dr. Iв SVENDSEN is thanked for help with amino acid sequencing. Mss. BIRGITTE Marcussen, Pia Breddam and Bodil CorNELIUSSEN, and Mr. THORKILD BEENFELDT are acknowledged for excellent technical assistance.

\section{REFERENCES}

1. Ainsworth. C. C. M. D. Gale \& S. Baird: The genetics of $\beta$-amylase isozymes in wheat 1 . Allelic variation among hexaploid varieties and intrachromosomal gene locations. Theor. Appl. Genet. 66, 39-49 (1983)

2. BRIGGS, D. E.: Hormones and carbohydrate metabolism in germinating cereal grains. In: Biosynthesis and Its Control in Plants (B. V. Milborrow, ed. ) pp. 219-277. Academic Press, London and New York (1973)

3. HeJGaARD. J: "Free" and "bound" $\beta$-amylase during malting of barley. Characterization by two-dimensional immunoelectrophoresis. J. Inst. Brew. 84. 43-46 (1978)

4. HeJgaARD, J.: Free and protein-bound $\beta$-amylase of barley grain. Characterization by two-dimensional immunoelectrophoresis. Physiol. Plant. 38, 293-299 (1976)

5. KRUGER, J.E.: Modification of wheat $\beta$-amylase by proteolytic enzymes. Cereal Chem. 56, 298-302 (1979)

6. LaBerGe. D. E. \& B. A. MARChylo: Heterogeneity of the beta-amylase enzymes of barley. J. Am. Soc. Brew. Chem. 41, 120-124 (1983)

7. Laberge, D. E. \& B. A. Marchylo: Changes in beta-amylase enzymes during kernel development of barley and the effect of papain as an extractant. J. Am. Soc. Brew. Chem. 44, 16-19 (1986)

8. Nummi. M.. R. Vilhunen \& T. M. EnARi: $\beta$-Amylase: I. $\beta$-amylases of different molecular size in barley and malt. Proc. 10th Congr., Eur. Brewery Convention, Stockholm, pp. 52-61. Elsevier, Amsterdam (1965)

9. Robyt. J. F.\& W. J. Whelan: The $\alpha$-Amylases. In: Starch and its Derivatives (J. Radley, ed. ) pp. 430-476. Chapman and Hall Ltd., London (1968)

10. Sargeant. J. G. \& T. S. Walker: Adsorption of wheat alpha-amylase isoenzymes to wheat starch. Starch 30, 160-163 (1978)

11. Svendsen, I. B. Martin \& I. Jonassen: Characteristics of Hiproly barley III. Amino acid sequences of two lysine-rich proteins. Carlsberg Res. Commun. 45, 79-85 (1980)

12. Visuri. K \& M. NUMmi: Purification and characterization of crystalline $\beta$-amylase from barley. Eur. J. Biochem. 28, 555-565 (1972)

13. Winter. A., K. EK \& V. B. ANDERSON: Analytical electrofocusing in thin layers of polyacrylamide gel. LKB Application Note 250 (1977)

Accepted by H. KLENOW 